\title{
1. INTRODUCTION AND SUMMARY OF ACTIVE-MARGIN DRILLING IN THE NANKAI TROUGH AND JAPAN TRENCH, DEEP SEA DRILLING PROJECT LEG $87^{1}$
}

\author{
William T. Coulbourn, Hawaii Institute of Geophysics, University of Hawaii ${ }^{2}$
}

\section{INTRODUCTION}

The location, directions, and rates of lithospheric plate convergence for most of the active margins of the world are well established by geophysical data. Yet even after 12 Glomar Challenger voyages devoted to drilling active margins, the expression of lithospheric convergence in the geologic features of the setting remains poorly understood. On a larger scale, the mechanisms by which plate convergence causes mountains to rise above subduction zones and the origin of continental rocks are a matter of conjecture. With these broad questions in mind, Leg 87, the last DSDP expedition dedicated to drilling active margins, was designed to investigate two very different regions: the Nankai Trough and the Japan Trench.

The IPOD Active Margin Panel (AMP) selected the Nankai Trough as the first target for Leg 87 drilling after viewing the migrated time section, Profile N55-3-1 (Fig. 1 and Frontispiece). This area holds a special interest for the Japanese IPOD constituency, but is of general interest to all those involved in studies of active margins. Subduction has occurred intermittently along the plate boundary at the Nankai Trough at least since the Mesozoic, and the present phase probably began with the opening of the Shikoku Basin in the early to middle Miocene (Karig, Ingle, et al., 1975; Larson et al., 1984). A landward-dipping zone of earthquake focii, the Wadati-Benioff Zone, typical of active margins, is limited to less than $150 \mathrm{~km}$ in the Nankai region (Kanamori and Tsumura, 1971; Aoki et al., 1982). Heat flow is also abnormally high compared to other subduction zones, and the expected trenchlike depression is much reduced. The southwestward continuation of a trend marked by the Zenisu Ridge forms a low but continuous swell that marks the seaward flank of the Nankai Trough offshore of Shikoku Island (Fig. 2). The trough itself is shallow compared to most trenches; depths range between 4000 and $4800 \mathrm{~m}$, only several hundred meters deeper than the Shikoku Basin.

On some profiles the ocean crust can be traced at least $60 \mathrm{~km}$ landward of the Nankai Trough (Nasu et al., 1982; Aoki et al., 1982). The tectonic contact between the overriding Japanese island arc and the Philippine Plate beneath is along a décollement near the base of

\footnotetext{
${ }^{1}$ Kagami, H., Karig, D. E., Coulbourn, w. T., et al., Init. Repts. DSDP, 87: Washington (U.S. Govt. Printing Office).

2 Present address: Hawaii Institute of Geophysics, University of Hawaii, 2525 Correa Road, Honolulu, Hawaii 96822.
}

the turbidite sequence accumulated in the trough. Beneath the décollement, a series of subhorizontal reflectors represent subducted equivalents of sediment deposited in the Shikoku Basin during the Pliocene ("Décollement" in Fig. 1). These subducted sediments are less than one-fourth of the total accumulation riding into the subduction zone at a rate of between 2 and $5 \mathrm{~cm} / \mathrm{yr}$. (Fitch and Scholz, 1971; Karig, Ingle, et al., 1975; Seno, 1977). Profile N55-3-1 indicates that more than three-fourths of that accumulation-more than $1 \mathrm{~km}$ of sediment-is involved in the deformation. Because the sedimentary column is thick, the Nankai Trough resembles sedimentchoked active margins, like Barbados (Moore, Biju-Duval, et al., 1984) and the Makran (White and Louden, 1982). A series of ridges emerges along thrusts rooted in the basal detachment beneath the landward slope of the Nankai Trough. Although each ridge ponds different amounts of sediment (Hilde et al., 1968), accumulations generally increase in thickness upslope as the spacing between ridges increases (Aoki et al., 1982). Bottom-simulating reflectors (BSRs) are recorded on some of the multichannel seismic profiles across the lower slope (Aoki et al., 1982). The Muroto, Tosa, and Hyuga basins are terraces in the bathymetric sense (Ludwig et al., 1973; Mogi, 1979) but are basins in a structural sense; accumulations in the Tosa Basin alone reach a thickness of $4.0 \mathrm{~km}$ (Yoshii et al., 1973). Flanking these basins to the north is a belt of sedimentary rocks called the Shimanto subgroupfolded and faulted sandstones and mudstones, which in places incorporate basaltic pillow lavas and radiolarian cherts (Taira, 1981; Taira et al., 1982).

The Nankai Trough was drilled at Leg 31 Sites 297 and 298 (Figs. 2 and 3 and Karig, Ingle, et al., 1975), but spot-coring and insufficient penetration left many questions unresolved. Also, at the time of the Leg 31 voyage no profile such as N55-3-1 existed. Resolution of thrust slices, deformed sediment packets, and subducting sedimentary section (Fig. 1) provided an excellent baseline from which Leg 87 could drill. The frontal thrust was a prime drilling target.

Farther north the Pacific lithospheric plate subducts beneath northern Honshu, their contact marked by the Japan Trench (Fig. 4). This margin was also drilled before, during two voyages rather than merely a part of one (Fig. 3 and von Huene et al., 1982). DSDP Leg 56, 57 was dedicated to testing the concept that the Japan Trench area is an accretionary margin along an island arc composed of continental crust (Arthur and Adelseck, 1980). Surprisingly, drilling indicated that (1) only the seaward tip of the landward slope might contain sed- 
Shot points

1500

1600

1700

1800

1900

2000

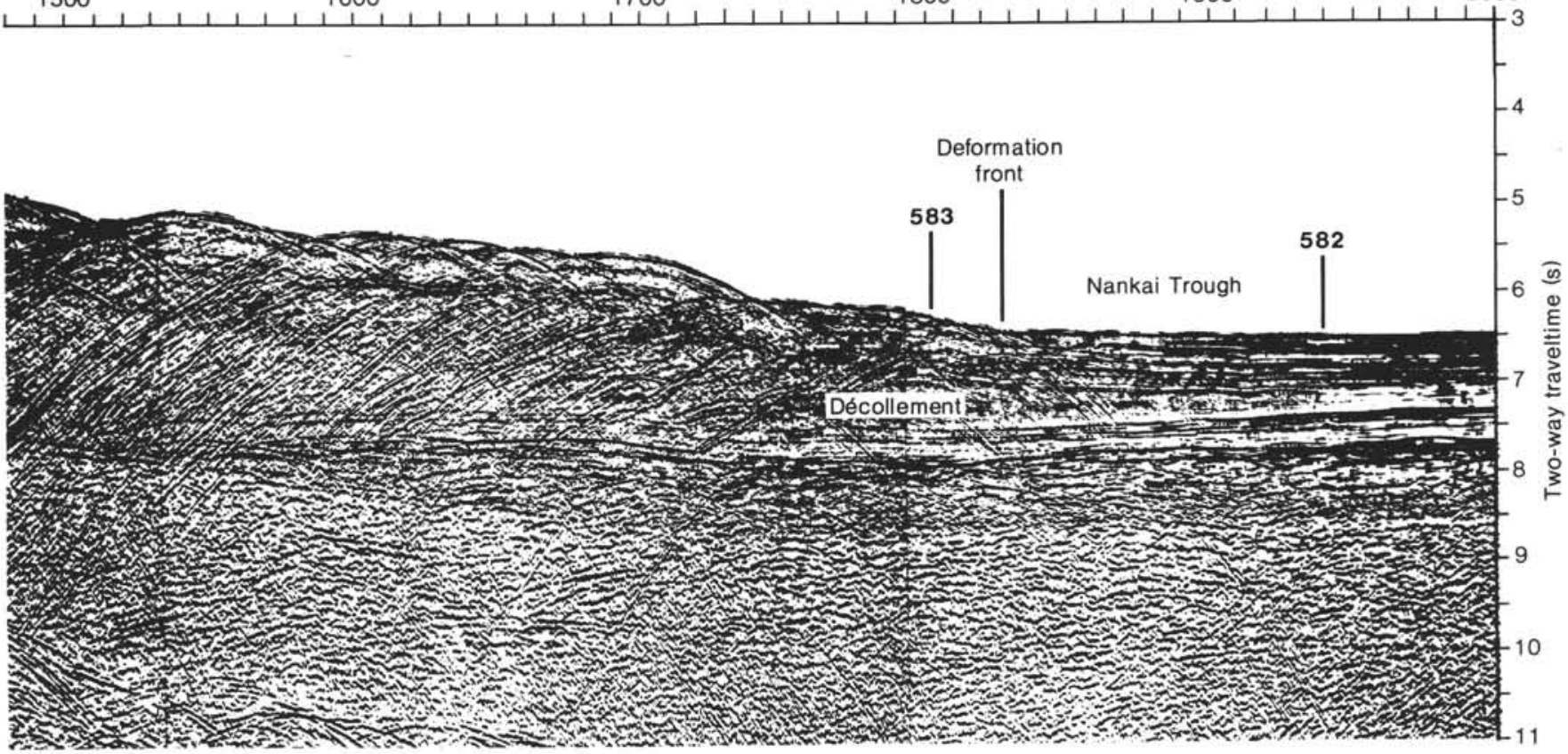

Figure 1. Migrated time section, Profile N55-3-1 (Nasu et al., 1982). See Figure 2 for location. Reflectors depict the smooth seafloor of the Nankai Trough between Shot Points 1820 and 2000 and the slope of the Japanese island arc between Shot Points 1480 and 1820 . Sub-bottom reflectors suggest increasing deformation of sedimentary horizons with decreasing shot point number (from southeast to northwest). Smooth, subhorizontal sub-bottom reflectors represent a basal décollement that dips landward between 7 and 8 degrees.

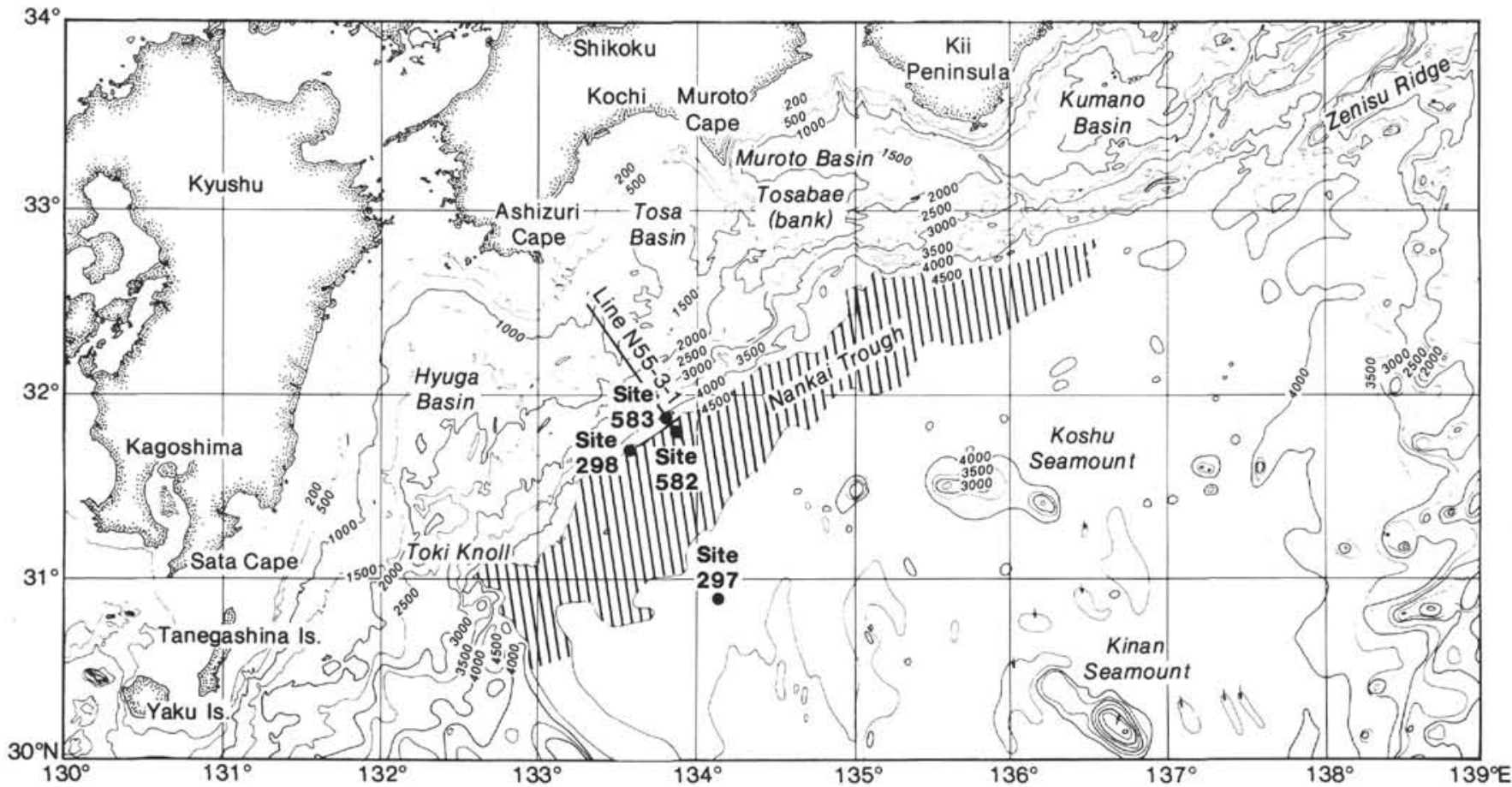

Figure 2. General bathymetry and prominent features of the Nankai Trough (after Nasu et al., 1982). Shaded area is Nankai Trough.

iment and rock accreting as a part of the current phase of subduction of the Pacific Plate, (2) the trench-slope break has subsided, and (3) andesitic volcanism occurred in the Cretaceous and early Paleogene.

These Leg 56, 57 results forced a reassessment of popular concepts regarding active margins. The finding of shallow-water deposits and dacitic cobbles at the base of Site 439 at $1150 \mathrm{~m}$ sub-bottom and $1656 \mathrm{~m}$ water depth (von Huene et al., 1978), fits neither the "trench-snow plow" cartoon (Den and Yoshii, 1970; Helwig and Hall, 1974), nor the "trench-slope" model (Seely et al., 1974), nor the "accretionary prism" concept (Karig and Shar- 
man, 1975). Although different with respect to their details, each of these ideas predicts accretion of sediment and rock scraped off of a lithosphere sinking into the Earth's mantle. The result should be uplift and seaward growth of a continental or island-arc margin. The concept gained general acceptance in the literature before testing in the field during IPOD active-margin drilling, because deep-water marine sediments are exposed along modern convergent margins in places like Barbados and Nias and in ancient terrane such as the Coast Ranges of California and the Nicoya Peninsula of Costa Rica, and particularly because seismic reflection profiles of active margins frequently show landward-dipping reflectors (see Coulbourn, 1981, for discussion and references). These reflectors are generally interpreted as dipping beds, but sometimes as thrusts, delimiters of accreted packets of sediment and rock sequentially peeled off a subducting plate and incorporated into the growing active margin. That geometry is clear in N55-3-1 (Fig. 1) but is also present in Line 78-3 across the Japan forearc (Fig. 5). Deep-water pelagic sediments and slices of ocean rock should be elevated into the forearc, instead of shallowwater deposits and island-arc-type volcanic rocks being submerged to bathyal depths.

As a direct outgrowth of DSDP drilling, the Japan Trench margin, like its counterpart the Mariana Arc (Hussong, Uyeda, et al., 1982), is now considered a "sediment-starved" active margin, on the opposite end of the spectrum from the Nankai Trough. The sedimentary cover on the subducting lithosphere is thin along these margins, in part because of great water depth and dissolution of the calcareous component. Whether influential in the subduction process or not, this lack of sediment cover is associated with truncated margins. In the case of the Japan Trench, the shallow-water deposits now submerged more than $2800 \mathrm{~m}$ beneath sea level suggested to the scientists on Leg 56, 57 that a now-foundered "Oyashio landmass" once existed to the east of the present Japanese archipelago. A concept akin to tectonic erosion at convergent margins (Fig. 6 and Scholl and Marlow, 1974) seemed the best explanation for this new "hard data." How "hard" are these data? What is the Oyashio landmass-local aberration or regional phenomenon? How did this landmass subside? Is tectonic erosion occurring along this margin now? What is the manifestation of such a process in the features of the rocks caught in this collision setting? Because these questions remained unanswered, the Japan Trench area remained a high-priority target for study.

Why aren't the basic questions regarding the dynamics of subduction answered after this extensive active-margin drilling (Fig. 3)? Poor drilling conditions, resulting in brecciated formations and caving holes that jam the drill string, gas pressure sufficient to blow the core sample out of the liner, and the potential safety hazard of drilling BSRs add to the usual woes of high waves, strong wind, and mechanical failure. In addition, properties of the sediments themselves conceal the dynamic processes. Diatomaceous hemipelagic mud constitutes most cores drilled from active margins of the world (Fig. 3).
Sparse carbonate-rich hemipelagic muds, sands, conglomerates, ash beds, and exotic pebbles constitute the remaining portion (Table 1). The whole sedimentary cover is generally pasty, becoming cohesive and brittle at shallow sub-bottom levels. The deposit is often fractured because of its actively deforming setting, so that it breaks apart on contact with the drill bit. Sedimentary structures are camouflaged by the brecciation of the sample and by its uniform olive gray color. Only indirectly related to the subduction process, these sediments reflect the position of many active margins beneath zones of upwelling and of highly productive surface waters. Even under the best of circumstances, it may be difficult to distinguish sedimentary provenance. For example, at the high-latitude sites of Legs 18 and 19 (Fig. 3), low faunal diversity and a high influx of Pleistocene terrigenous sediment prevented differentiation of ocean and slope deposits (Kulm, von Huene, et al., 1973). At the Leg 60 sites (Fig. 3), because of the great depth of the Pacific Plate, pelagic red brown clays, not chalks, are brought into the subduction zone. Those clays would be difficult to trace were they tectonically mixed with hemipelagic sediments accumulating on the Mariana forearc-subtle color contrasts and differences in ash and siliceous microfossil content would be the most useful labels for these different sediments. One of the reasons for selecting the Leg 66 and 67 drill sites rested on a supposed diversity of sedimentary facies (Coulbourn et al., 1982). Chalks accumulated on the Cocos Plate should have contrasted sharply with hemipelagic muds on the Central American margin (Fig. 3). Unfortunately, the 200-m-thick carbonate sediment accumulated on the Cocos Plate at Site 495 is buried under $160 \mathrm{~m}$ of olive gray hemipelagic mud very much like its counterpart on the landward side of the trench. A "black-white" contrast of both nearsurface sediment type and microfauna does not exist, even across the Middle America Trench.

In this respect the Nankai slope holds little promise; a lack of contrasting sediment was known to exist even before Leg 87. The calcite compensation depth (CCD) in the northwestern Pacific is about $4000 \mathrm{~m}$ (Berger et al., 1976); therefore, carbonate-poor, olive gray hemipelagic mud is accumulating offshore of Shikoku Island, in the Nankai Trough, and in the Shikoku Basin. The general absence of calcareous microfossils and rapid sediment accumulation limit the power of micropaleontology to resolve stratigraphic horizons both in the Nankai Trough and on the adjacent Shikoku margin. Instead of relying on the primary aspects of the sediment, researchers for Leg 87 focused on their physical properties combined with the stratigraphic control afforded by the sharply resolved features displayed in Profile N55-3-1. Are sediment porosity, permeability, shear strength, consolidation, and other attributes enough to define processes within a deforming margin? Do these properties change abruptly across the major tectonic features displayed in the seismic profile? What are the contrasts in microfabric and in structural features diagnostic of sediment within an "accretionary prism" compared to their counterparts beneath the basal décollement? 

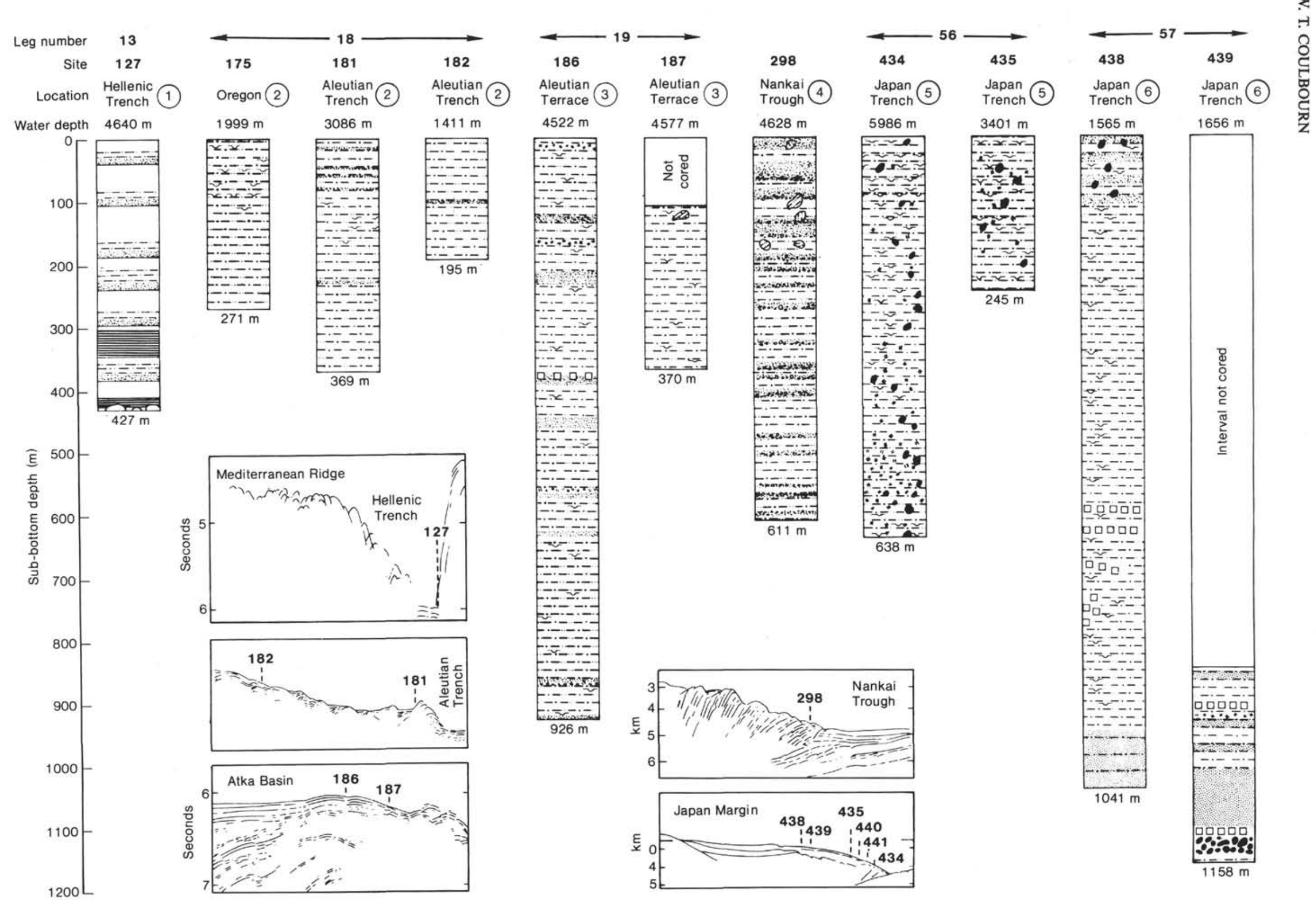


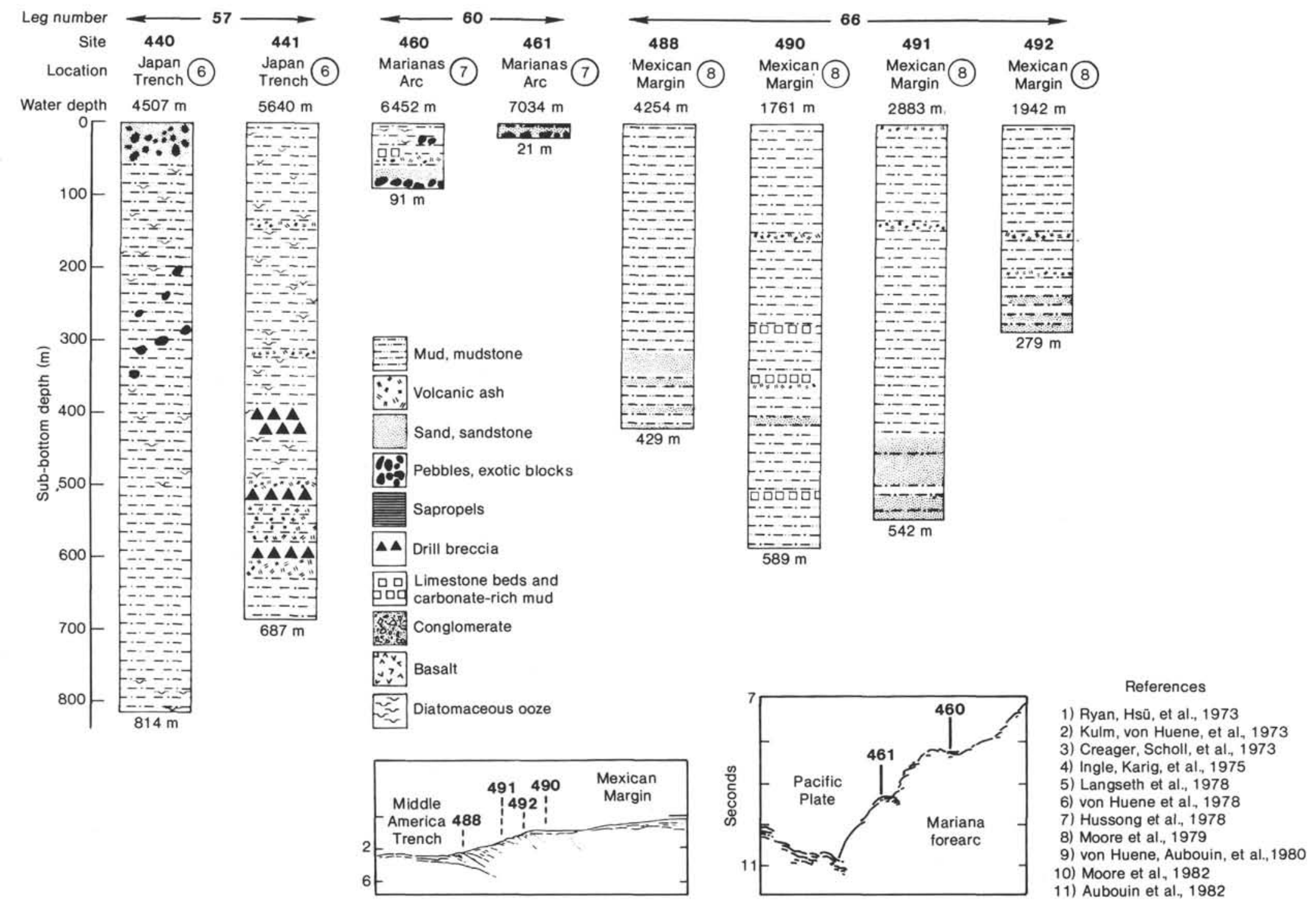

Figure 3. Lithologic summaries: DSDP sites on other convergent margins (Table 1). Circled numbers identify references cited. Insets locate sites on seismic reflection profiles. Total sub-bottom depth is indicated at the bottom of each column. 

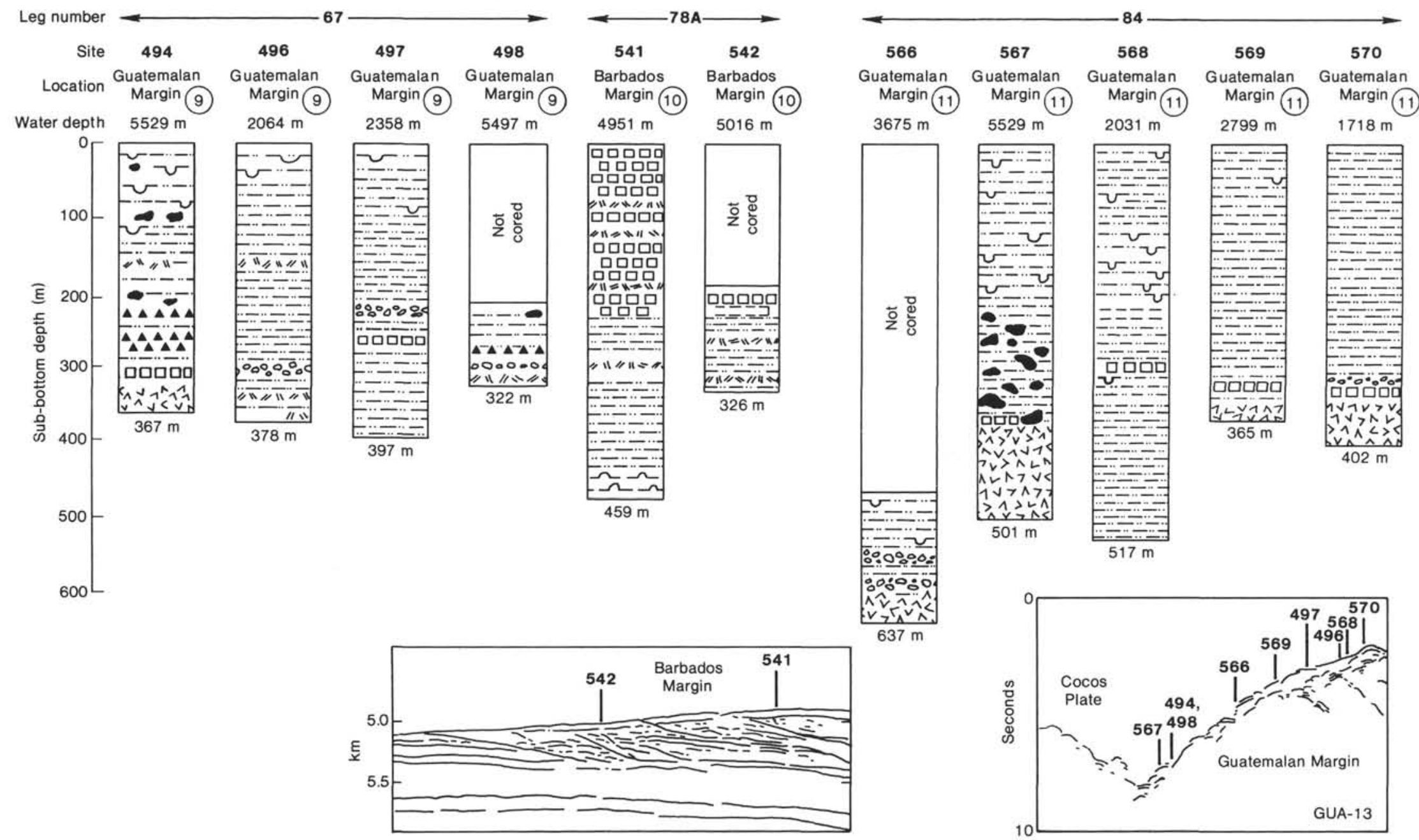

Figure 3. (Continued). 


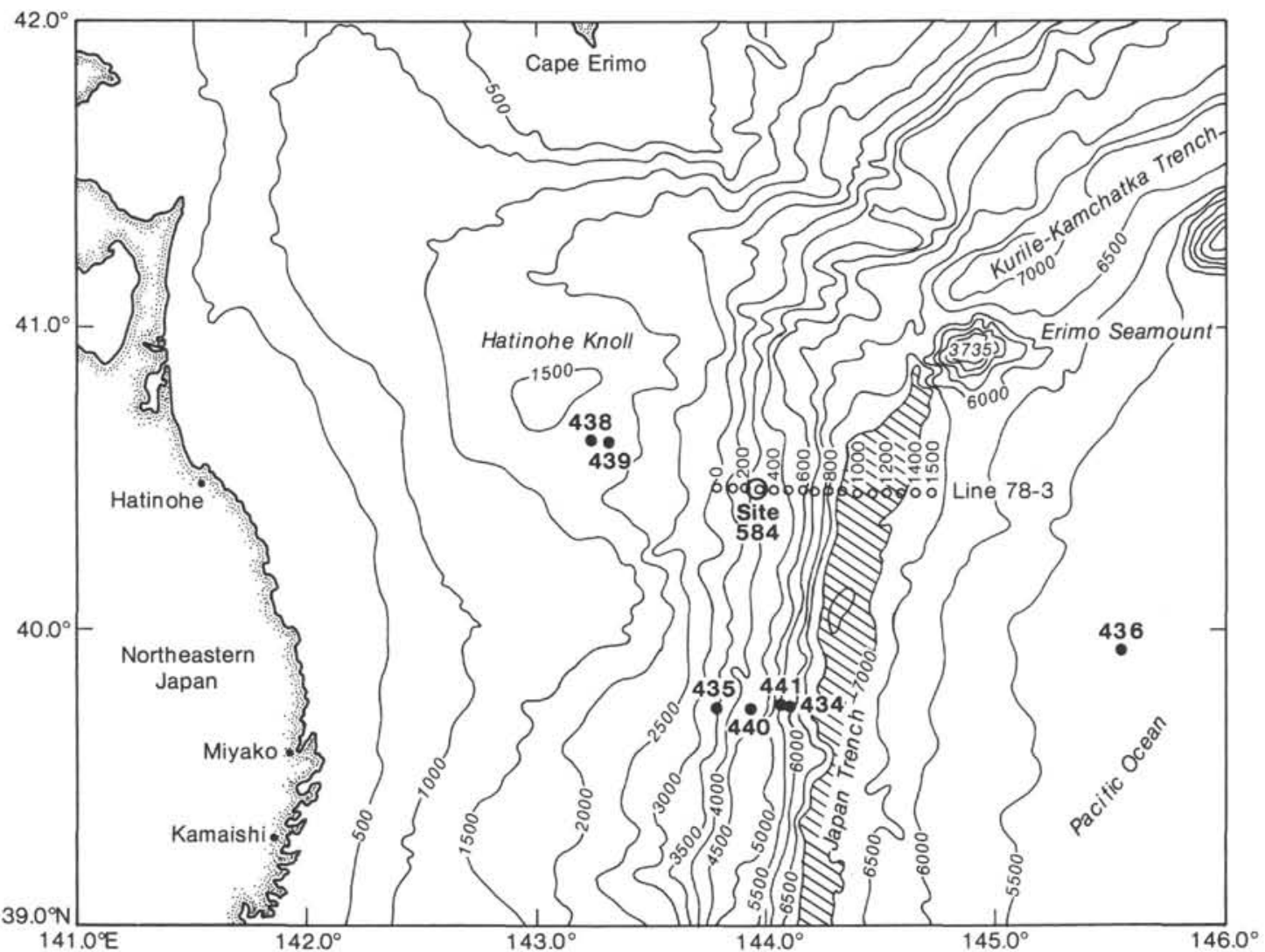

Figure 4. General bathymetry and prominent features of the Japan Trench offshore of northeastern Honshu (Nasu et al., 1979). Shaded area is Japan Trench.

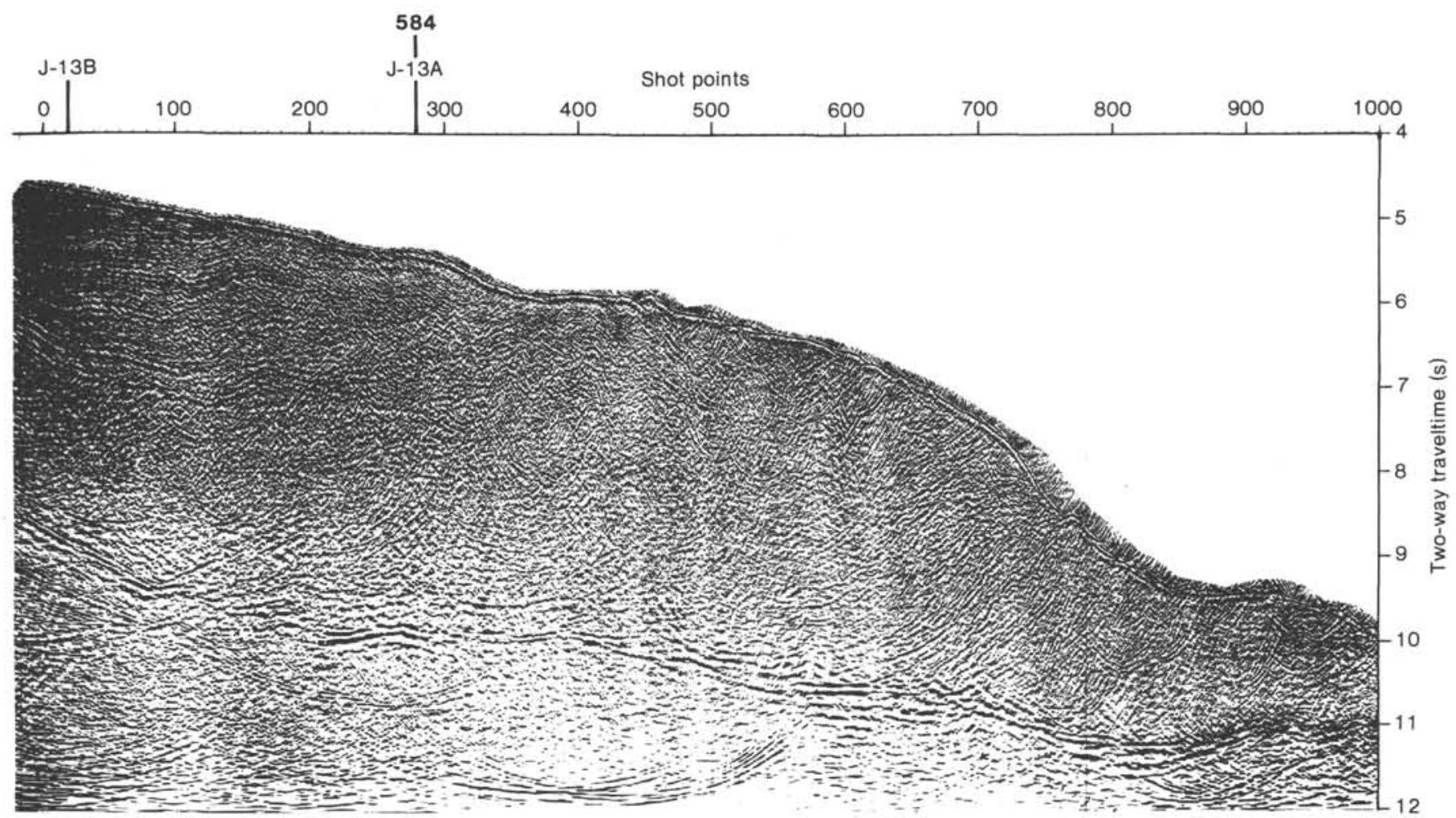

Figure 5. Migrated time section, Line ORI 78-3 (Nasu et al., 1979). See Figure 4 for location. 

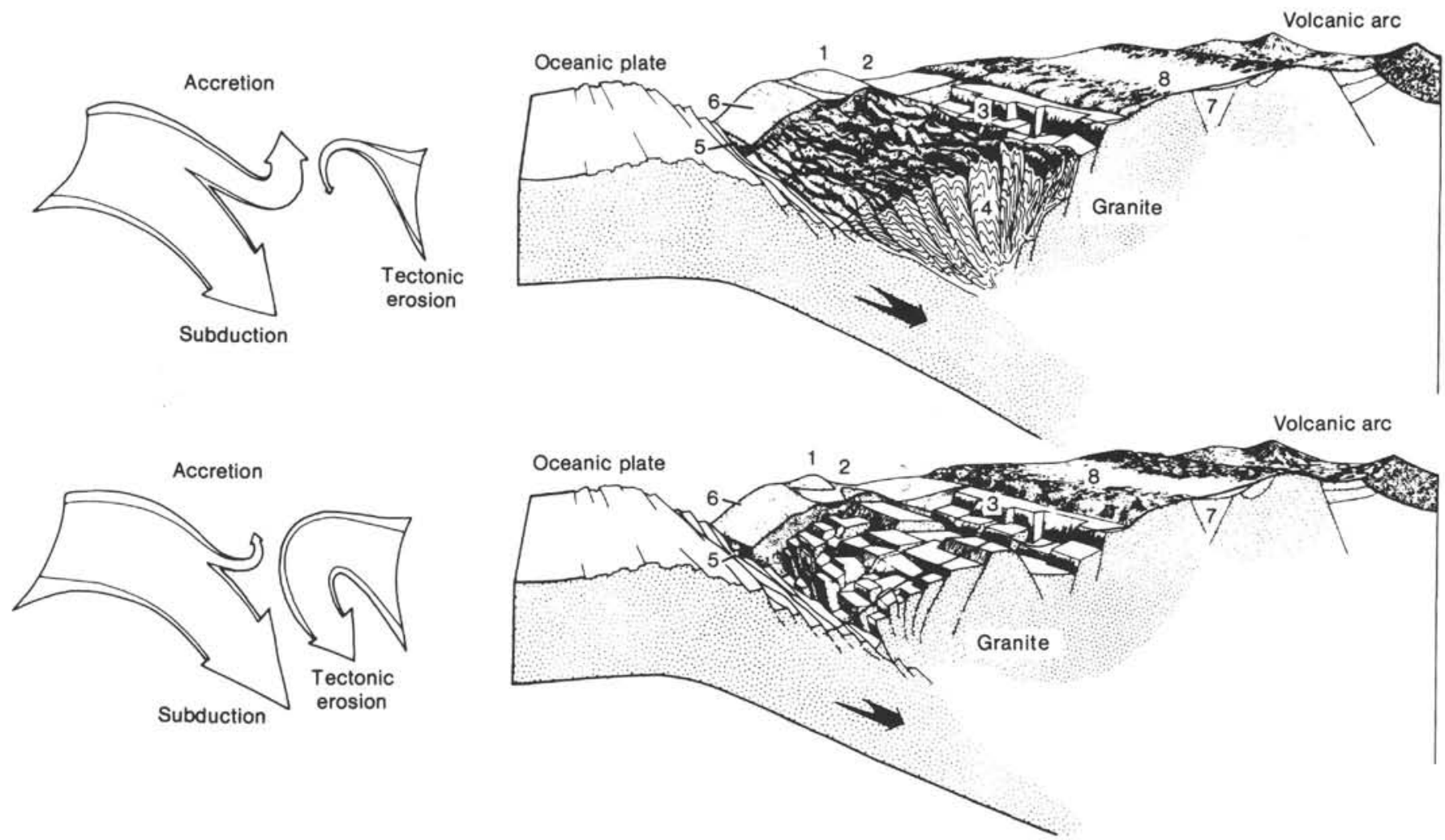

Figure 6. Accretionary and erosional end members for convergent margins (from Coulbourn, 1981). Arrows indicate relative amounts of rock and sediment subducted, accreted, or tectonically eroded: $1=$ structural high; $2=$ forearc basin; $3=$ block-faulted continental rock; $4=$ accretionary prism; $5=$ trench axis turbidites; $6=$ hemipelagic drape; $7=$ ancient sediments; and $8=$ coastal batholith.

\section{SUMMARY OF RESULTS}

\section{Nankai Trough}

A transect of five sites was identified and three recommended for the Nankai Trough, the first in the trough itself, the remaining two on the landward slope. The transect was selected to investigate: (1) subduction dynamics, namely, the physical properties of sediments; (2) kinematics and structural evolution of the forearc, in particular, the identification of trajectories of sediment and rock in a subduction zone; and (3) sedimentation processes, both a determination of the relative importance of gravitational and tectonic processes in the deformation of the trench slope and a refinement of concepts regarding sedimentation in deep-sea fans. Additionally, the magnetostratigraphy, biostratigraphy, and tephrastratigraphy, as well as heat flow, paleoceanography, geochemistry of clathrates, and nature of pore water, were all distinct aspects of this investigation.

\section{Site 582}

Site 582 is located on the floor of the Nankai Trough about $2 \mathrm{~km}$ south of a deformation front, where thrusting associated with subduction begins, and is only $7 \mathrm{~km}$ seaward of Site 583 (Figs. 1 and 2 and Karig et al., 1983). Holes 582 and $582 \mathrm{~A}$ achieved only shallow penetration because of mechanical problems that are more or less expected with the beginning of each new Glomar Challenger voyage. Hole 582B penetrated about $560 \mathrm{~m}$ of Quaternary trench axis turbidites before reaching the lower Quaternary and upper Pliocene hemipelagic sediment of the Shikoku Basin stratigraphic section (Fig. 7). The samples are generally dark olive gray hemipelagic clays, gray silts and turbidites, with some lighter, but not even pale brown, carbonate-rich intervals. Coarse sand turbidites and associated carbonates decrease in frequency with sub-bottom depth, but we saw no overall downhole fining of sands. We relied on the correlation of logging profiles and intervals of low recovery at Site 583 in identifying sandy horizons at Site 582 . The upper Quaternary sediments filling the trench are turbidites, which include volcanic glass, lithic fragments, heavy minerals, red chert, well-preserved mixtures of shallow-water and deep-water benthic foraminifers and both marine and nonmarine diatoms. The suite of components indicates feeding of the Nankai Trough depocenter primarily by detritus from the Izu Peninsula about $400 \mathrm{~km}$ to the northeast along with the derivation of some sediment from source terranes of Shikoku.

Accumulation rates for this section range from $900 \mathrm{~m} /$ Ma before $0.4 \mathrm{Ma}$ to $300 \mathrm{~m} / \mathrm{Ma}$ after $0.4 \mathrm{Ma}$ (site chapter, Site 582 , this volume). These results are broadly averaged and depend on two biostratigraphic markers and one magnetic reversal; nevertheless, it is certain that accumulation rates are in general very high. Sediment porosity decreases downhole to about $550 \mathrm{~m}$ sub-bottom and then increases as the top of the Shikoku Basin sediments are penetrated. From about $625 \mathrm{~m}$ sub-bottom downward, porosity again decreases. 
Table 1. Abbreviated description of lithology of cores taken from DSDP drill sites located on active margins.

\begin{tabular}{|c|c|}
\hline Site & Description \\
\hline 127 & $\begin{array}{l}\text { Turbidite and contourites, graded sands and marly oozes, ash layers, } \\
\text { and sapropels }\end{array}$ \\
\hline 175 & $\begin{array}{l}\text { Diatomaceous clayey silt and carbonate-bearing mud, silt beds, and } \\
\text { sand beds }\end{array}$ \\
\hline 181 & Diatomaceous silty clay, silt and sand beds \\
\hline 182 & Silty clay and clayey silt beds \\
\hline 186 & $\begin{array}{l}\text { Diatomaceous silty clay, volcanic ash, sand, and carbonate mud; gassy } \\
\text { in sand layers between } 0 \text { and } 200 \mathrm{~m} \text { sub-bottom }\end{array}$ \\
\hline 187 & Diatomaceous silty clay \\
\hline 298 & Turbidites, 0-80 m proximal, $180-611 \mathrm{~m}$ distal mud, silt, and sand \\
\hline 434 & Diatomaceous mud and mudstone, volcanic ash \\
\hline 435 & Diatomaceous mud, volcanic ash, terrigenous sand \\
\hline 438 & $\begin{array}{l}\text { Pebbly sand, diatomaceous mud, ash layers, limestone beds, dewater- } \\
\text { ing veinlets }\end{array}$ \\
\hline 439 & Diatomaceous mud and sand, volcanic ash \\
\hline 440 & Diatomaceous mud and claystone, ash layers, dewatering veinlets \\
\hline 441 & Diatomaceous mud and claystone, volcanic ash, dewatering veinlets \\
\hline 460 & $\begin{array}{l}\text { Redeposited and mixed sediments, siliceous ooze, calcareous and vitric } \\
\text { mud, pebble layer }\end{array}$ \\
\hline 461 & Reworked sediment and cobbles of igneous and metamorphic rock \\
\hline 488 & Hemipelagic mud, mudstone and sand \\
\hline 490 & Hemipelagic mud and mudstone, gassy frozen sediment \\
\hline 491 & Hemipelagic mud, mudstone and sand, gassy frozen sediment \\
\hline 492 & $\begin{array}{l}\text { Hemipelagic mud, mudstone and sand, gassy frozen sediment, slicken- } \\
\text { sided anastomosing fractures }\end{array}$ \\
\hline 494 & $\begin{array}{l}\text { Diatomaceous hemipelagic mud, becoming carbonate-bearing mud- } \\
\text { stone below } 250 \mathrm{~m} \text {, ophiolitic basement rock below } 325 \mathrm{~m} \text { sub- } \\
\text { bottom }\end{array}$ \\
\hline 496 & Diatomaceous nannofossil mud and pebbly mudstone \\
\hline 497 & $\begin{array}{l}\text { Diatomaceous nannofossil mud, } 0-175 \mathrm{~m} \text {; sandy, pebbly hemipelagic } \\
\text { mud and mudstone with limestone clasts and coarse-grained } \\
\text { intervals interbedded with ice }\end{array}$ \\
\hline 498 & Hemipelagic mud and mudstone with gas-rich, coarse-grained intervals \\
\hline 541 & $\begin{array}{l}\text { Nannofossil ash-bearing mud, } 0-215 \mathrm{~m} \text {; greenish gray hemipelagic } \\
\text { mud and mudstone, } 215-459 \mathrm{~m}\end{array}$ \\
\hline 542 & $\begin{array}{l}\text { Marly nannofossil, ash-bearing ooze, } 0-240 \mathrm{~m} \text {, bioturbated hemipelag- } \\
\text { ic mud and mudstone, } 240-326 \mathrm{~m}\end{array}$ \\
\hline 566 & Siliceous mud, sandstone and mudstone, and serpentinite \\
\hline 567 & $\begin{array}{l}\text { Diatomaceous hemipelagic mud, 0-215 m; boulder mud formation, } \\
215-320 \mathrm{~m} \text {; serpentinite, } 320-355 \mathrm{~m} \text {; limestone, 355-376 m; and } \\
\text { dismembered ophiolitic rocks, 376-501 m }\end{array}$ \\
\hline 568 & $\begin{array}{l}\text { Diatomaceous hemipelagic mud with dispersed gas hydrate in the } \\
\text { lower } 200 \mathrm{~m}\end{array}$ \\
\hline 569 & $\begin{array}{l}\text { Diatomaceous hemipelagic mud and mudstone, } 0-355 \mathrm{~m} \text {, greenschist } \\
\text { facies metamorphosed gabbro and diabase }\end{array}$ \\
\hline 570 & $\begin{array}{l}\text { Diatomaceous hemipelagic mud and mudstone and massive gas hy- } \\
\text { drate overlying serpentinized peridotite }\end{array}$ \\
\hline
\end{tabular}

Note: Lithologic columns and reference citations are listed in Figure 3.

The average heat flow at Site 582 is 1.51 heat flow units, ${ }^{3}$ significantly less than the values obtained by nearsurface probes in the trench. Depression of these values might arise from the expulsion of pore water from the hemipelagic sediment of the underlying Shikoku Basin section.

\section{Site $\mathbf{5 8 3}$}

Originally, two holes were planned for Site 583. A "safety" hole of shallow penetration was to test for the presence of gas and, depending on the outcome, the second hole would be drilled landward and to a greater subbottom depth, penetrating a thrust at $600 \mathrm{~m}$ and continuing to $1000 \mathrm{~m}$ sub-bottom or more. For a variety of reasons (see Operations section, site chapter, Site 583,

\footnotetext{
${ }^{3}$ Heat flow unit (or $\left.\mathrm{HFU}\right)=\times 10^{-6} \mathrm{cal} /\left(\mathrm{cm}^{2} \cdot \mathrm{s}\right)$.
}

this volume), eight holes were ultimately drilled at Site 583.

The four hydraulic piston core (HPC) holes were very successful. High-resolution images of the seafloor were lacking, so location of these holes with respect to the surrounding morphology of the seafloor is based on $3.5-\mathrm{kHz}$ profiles. Hole $583 \mathrm{~A}$ is the farthest landward and was drilled on a terrace, of unknown lateral extent. Hole 583 sampled the sedimentary cover at a location designated for the deep hole designed to recover the stratigraphic section above the underlying décollement. Holes 583B and 583C are located farther seaward and sampled at the location of the planned Site 583 safety hole.

The sediment recovered at each of these locations is dark gray to dark olive gray hemipelagic mud. The ordinary aspect of these samples ends with their color-the wealth of detail recovered far surpassed our expectations. The cut cores display a sequence of finely graded beds; they are about $10 \mathrm{~cm} /$ cycle and are occasionally interrupted by layers of ash and vitric sand. This fine structure either does not exist or, more likely, was completely destroyed in the process of rotary drilling at Site 582 . Foraminifers are common only in the sand layers, a result of rapid burial, which preserved their solution-susceptible tests from corrosive deep waters. The benthic foraminifers were redeposited from shallower depths. Plant fragments are common and locally abundant. As at Site 582 , carbonate content is generally low, except for occurrences of crystal aggregates. As large as $5 \mathrm{~cm}$, these pale yellow crystalline masses consist of rhombohedral zoned crystals (10-50 $\mu \mathrm{m})$ embedded in a porous ground mass of fine acicular calcareous grains. These calcium carbonate hexahydrates would have been completely dispersed and probably lost to the observer were they rotary-cored. These crystals are stable under conditions other than surface pressure and temperature. By the time of the Leg 87 meeting a year after the cruise, the aggregates had completely disappeared, leaving only their rhombohedral molds. The crystals were generally associated with the basal, silty and sandy layers of the turbidite cycles. In Holes 583B and 583C, these beds dip strongly seaward then flatten abruptly at the base of the holes, and they could form the seaward limb of a hanging-wall anticline (Karig et al., 1983).

The safety hole, 583D, was rotary-drilled at the location of Holes 583B and 583C. Drilling was slow and recovery poor $(25 \%)$. Like the upper part of the stratigraphic section at Site 582, the deeper cores from Hole 583D contain trace fossils of Chondrites, graded silts, and scattered dark gray green laminations. Holes 583E, $583 \mathrm{~F}$, and $583 \mathrm{G}$ deepened HPC Hole 583, and the samples recovered resemble the sediment cored in the upper part of Hole 582B. Sands are irregularly distributed throughout the section, but their primary structure is completely remolded by drilling. Large pumice clasts, ash-rich blebs and deformed ash layers are scattered throughout, and several large carbonate nodules were recovered. Both siliceous and calcareous microfossils are poorly preserved and only common to rare; the oldest sediment cored at Site 583 is Quaternary. Poor recovery 


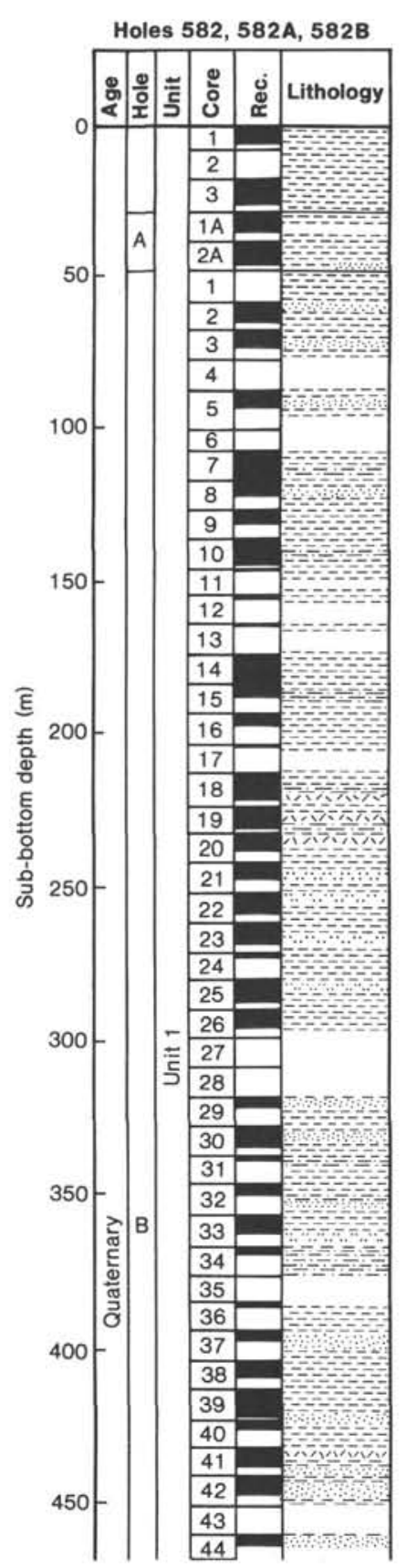

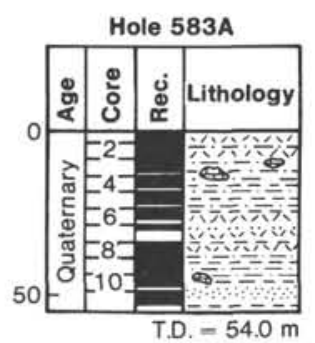
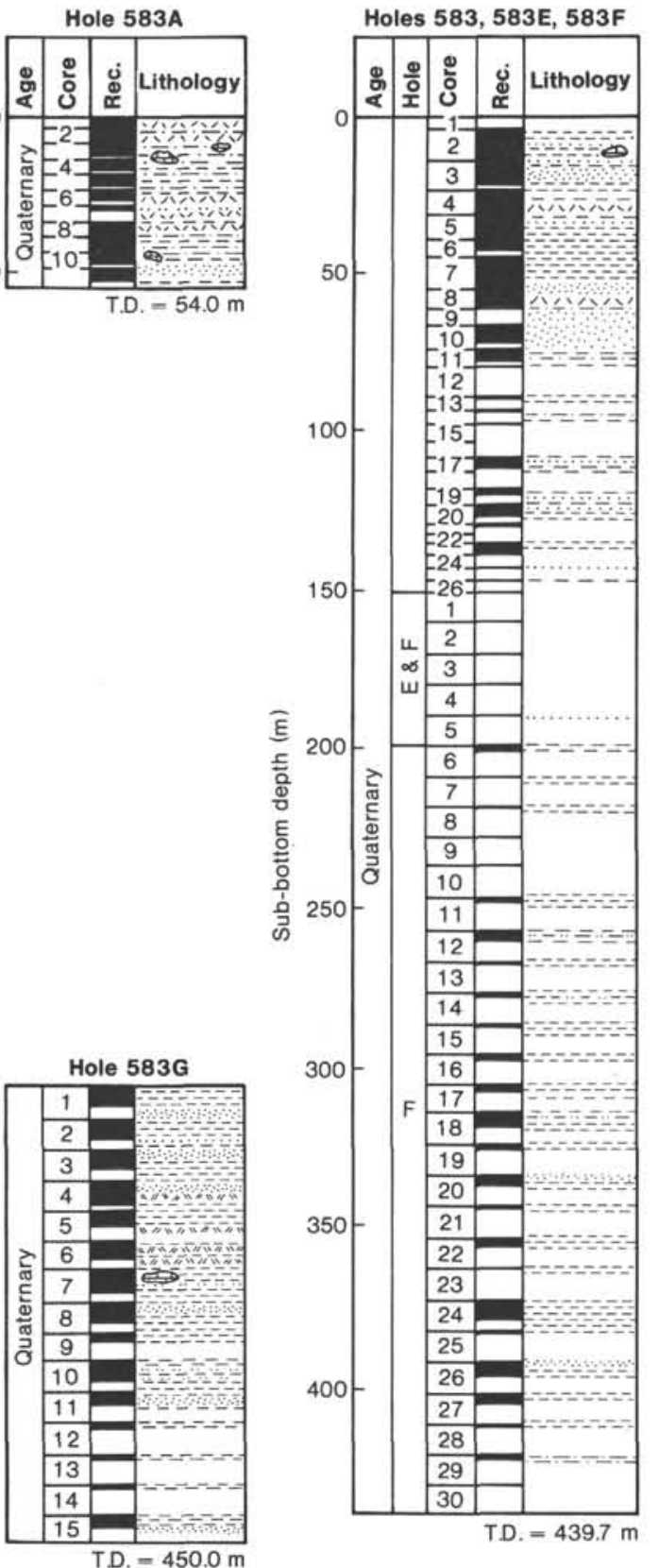
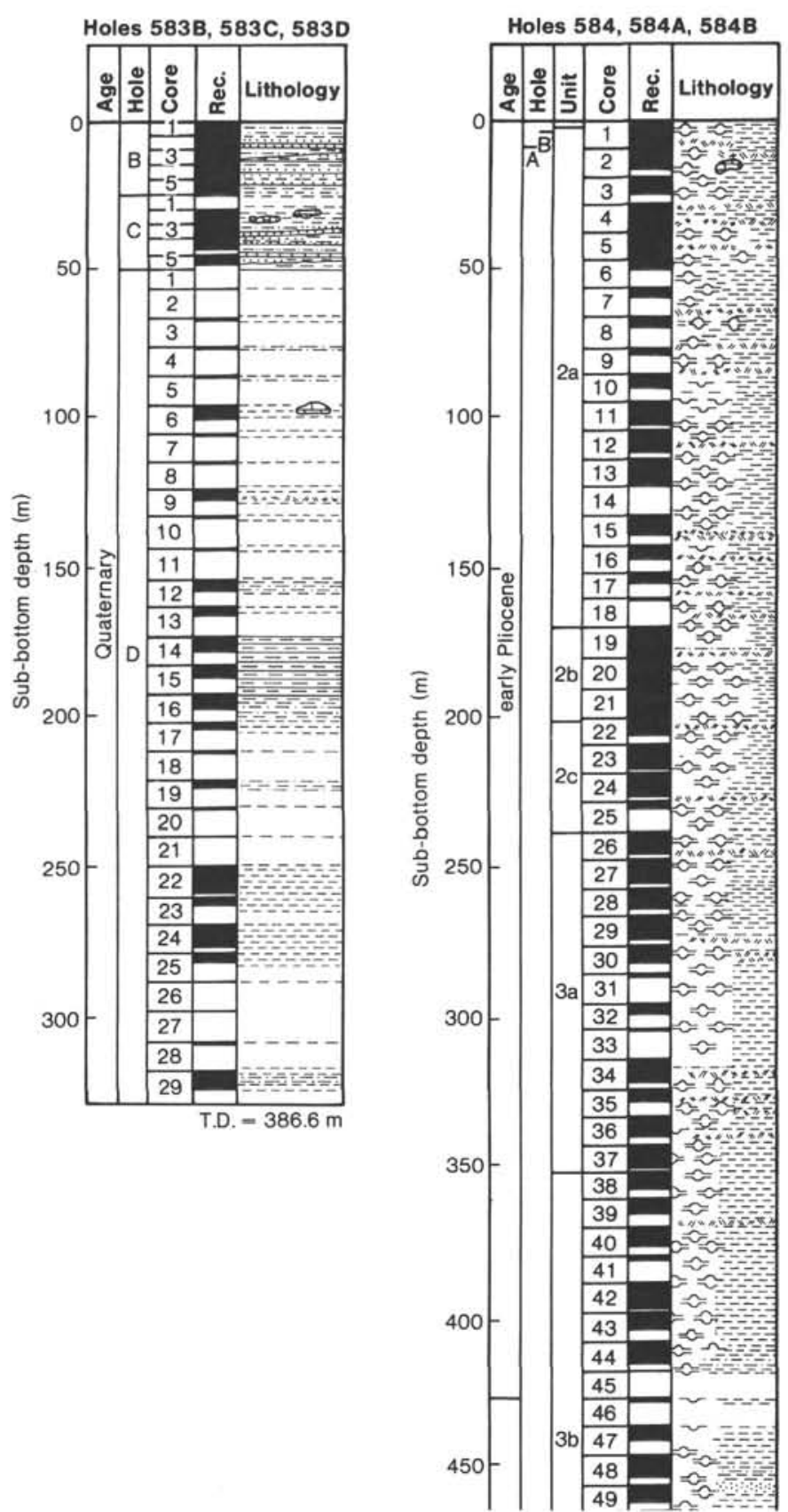

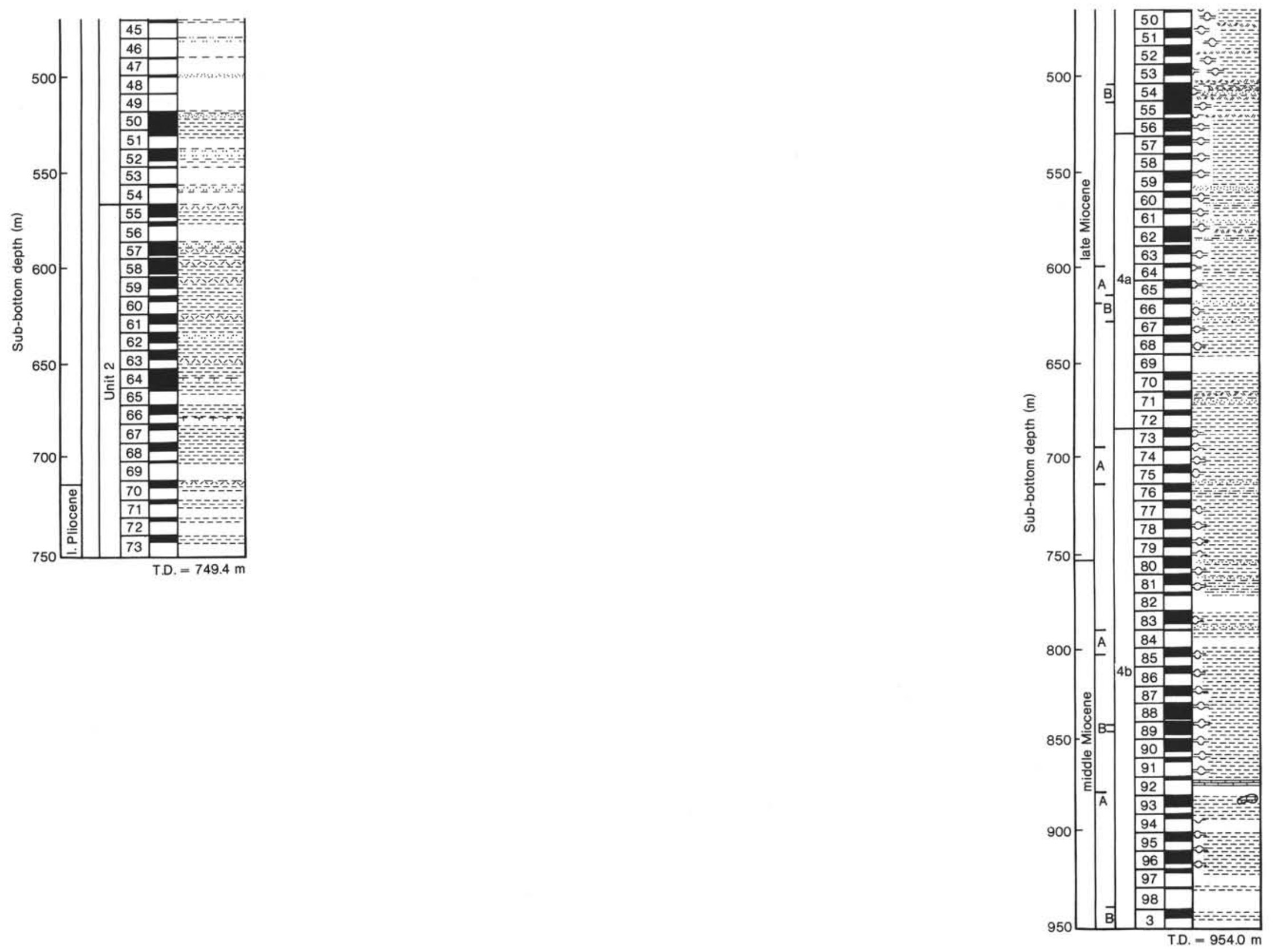
and drilling disturbance of the sediment that was recovered precluded documentation of changes in physical properties of the sediment expected at 60 and $160 \mathrm{~m}$ sub-bottom, depths where coring intersected major reflectors interpreted as thrust faults (Fig. 1). The sediment is fissile, and porosity decreases as shear strength increases with sub-bottom depth. The porosity gradient of the trench-fill sediments at Site $\mathbf{5 8 2}$ is slightly greater at Site 583, and the average porosity in the entire section at Site 583 (down to basement) is much less than that at Site 582 (Bray and Karig, 1985). Although gas was present, both its concentration and the ratio of ethane to methane are so low that an obvious safety hazard does not exist, at least within the sub-bottom depths reached at Site 583. Despite our repeated attempts, even after eight holes, penetration at Site 583 reached only $450 \mathrm{~m}$ sub-bottom (Fig. 7)-far short of our intended goal of 600 to $1000 \mathrm{~m}$.

\section{Summary of Nankai Trough Drilling}

Intended as a complementary pair, the two holes at the Nankai Trough produced results that are akin to having two left shoes. Site 582 was rotary-cored to great depth $(749.4 \mathrm{~m})$ with adequate overall recovery $(41 \%)$. Site 583 was hydraulic-piston-cored at four different locations with excellent overall recovery $(77 \%$, the average of four holes), but, as expected, with only shallow penetration. Four attempts were made to rotary-core Site 583, but for a variety of external reasons rotary-coring achieved only shallow penetration and very poor recovery $(22 \%$, average for four holes). Hole 583F was logged continuously for almost $200 \mathrm{~m}$. These results leave open the possibility for some very rewarding drilling in the future. Site 582 should be logged and piston-cored for a comparison with the existing data at Site 583; Site 583 should be rotary-cored to a sub-bottom depth at least commensurate with that reached at Site 582. The chances for success are good because, unlike drilling conditions on other active margins, conditions at the holes drilled in the Nankai slope are relatively stable and the gas content is low.

\section{Japan Trench}

The main objective in drilling the Japan Trench was to investigate the history of vertical motion of the continental margin near the trench and to penetrate a basal unconformity. Subsidence, probably associated with tectonic erosion, persisted throughout the Miocene, diminished in the Pliocene, and may have been followed by a slight amount of uplift since the beginning of the Pleistocene (Arthur et al., 1980). Is this history unique to the previously drilled sites, or is it representative of the entire forearc?

\section{Hole 584}

Site 584 is located on a terrace about $42 \mathrm{~km}$ landward of the trench axis. This terrace separates the upper slope from the steeper lower slope that continues to the trench axis at $7300 \mathrm{~m}$ (Fig. 5). The water depth is $4114 \mathrm{~m}$ at Site 584 and continuous coring reached another $954 \mathrm{~m}$ (Fig. 7). The oldest sediment recovered is middle Mio- cene, the oldest ever cored from the outer slope of the Japan Trench.

The uppermost $4 \mathrm{~m}$ at Hole 584 is upper Pleistocene sediment underlain without a lithologic contrast by soft lower Pleistocene diatomaceous mud and mudstone. The sediment stiffens near $90 \mathrm{~m}$ sub-bottom, and diatom content gradually decreases throughout the $954 \mathrm{~m}$ cored. The Pliocene/Miocene boundary occurs near $584 \mathrm{~m}$ subbottom without lithologic contrast. The sedimentary rock gradually becomes more bioturbated, the occurrence of healed fractures becomes more common, and the network of dewatering veinlets becomes more pervasive. These sedimentary and structural features combine to produce the "paisley," or varicolored, appearance of the lower part of the Site 584 lithologic section. In most cases healed fractures preserve a record of small-scale normal faulting, but examples of reverse faulting are also common.

The frequency of ash layers, dispersed glass, and ash pods suggests that onshore volcanic activity increased toward the end of the late Miocene and continued through the early Pliocene.

Authigenic carbonate nodules, including siderite, are disseminated in the lower Pliocene sediments and are frequently intercalated with ash layers or dispersed volcanic ash concentrations.

Except for diatoms, other microfossils are rare and poorly preserved at Site 584 . The diatom biostratigraphy of Site 584 corresponds to that of Site 438/439, located about $70 \mathrm{~km}$ to the northwest. Rates of accumulation estimated from selected datum levels range from a high of 200 to $70 \mathrm{~m} / \mathrm{Ma}$ for the early Pliocene and latest Miocene, to a low of $20 \mathrm{~m} / \mathrm{Ma}$ for the early late Miocene through late middle Miocene. Paleomagnetic measurements render corresponding rates: $120 \mathrm{~m} / \mathrm{MA}$ after 7.7 $\mathrm{Ma}$ and $50 \mathrm{~m} / \mathrm{Ma}$ before that time. Microfossil assemblages provide no evidence of a shoaling of the seafloor, even at the base of Hole 584 .

\section{Holes 584A and 584B}

The basal unconformity, which was the deep objective of Site 584, proved undrillable. In an effort to sample this horizon, Holes 584A and 584B were offset to the landward and to the seaward side of Hole 584, respectively. Both were spot-cored, and both terminated at about $940 \mathrm{~m}$ sub-bottom, at which point drilling rates abruptly decreased, the holes caved, and the drill string became stuck. Although the deep objective was not reached, these holes provided some valuable insights into sub-bottom structure. Correlative biostratigraphic datum levels and corresponding sedimentary lithologies are found at 500 and $700 \mathrm{~m}$ sub-bottom in all three holes. These horizons match despite the fact that bedding in the lower portion of Hole 584 dips steeply seaward. In the absence of folding, the only way that seaward dips can range between 20 to $70^{\circ}$ at each hole and horizons can remain at a uniform level is for the vertical offset to be taken up along faults. Because reflectors are subparallel and horizontal (Fig. 5), such a fault system must consist of a network of offsets, each with only a small amount of displacement; the scale of the system is prob- 
ably too small to be recorded in the reflection profiles. One reconstruction employs a series of landward-dipping, listric normal faults (Karig et al., 1983). Alternatively, gravitational sliding of an extensive sedimentary accumulation (after fig. 20 of Moore and Biju-Duval, 1984) could produce a similar configuration.

\section{Summary of Japan Trench Drilling}

Reflectors displayed in the seismic sections across the Japan forearc represent continuous strata only in a broadly averaged sense. Seaward-dipping beds and vertical offsets are beyond the resolving power of multichannel seismic stratigraphy. A long history of deformation and accumulation of diatomaceous hemipelagic mud is recorded in the Miocene and also in the younger sediments that have accumulated on the deep-sea terrace east of Honshu. Evidently, extensional tectonics have prevailed since the middle Miocene, and Site 584 was already at bathyal depths by the late Miocene.

\section{ACKNOWLEDGMENTS}

Thanks go to Johanna Resig and Dan Karig, and to Barbara Jones and Elizabeth Whalen for their critical reviews and editorial polish of this chapter. This is Hawaii Institute of Geophysics Contribution Number 1619 .

\section{REFERENCES}

Aoki, Y., Tamano, T., and Kato, S., 1982. Detailed structure of the Nankai Trough from migrated seismic sections. In Watkins, J. S., and Drake, C. L., (Eds.), Studies in Continental Margin Geology: Tulsa (Am. Assoc. Pet. Geol. Mem.), 34:309-322.

Arthur, M. A., and Adelseck, C. G., Jr., 1980. Acknowledgments, introduction, and explanatory notes: the Japan Trench transect, Legs 56 and 57, Deep Sea Drilling Project. In Scientific Party, Init. Repts. DSDP, 56, 57 Pt. 1: Washington (U.S. Govt. Printing Office), $3-21$.

Arthur, M. A., von Huene, R., and Adelseck, C. G., Jr., 1980. Sedimentary evolution of the Japan fore-arc region off northern Honshu, Legs 56 and 57, Deep Sea Drilling Project. In Scientific Party, Init. Repts. DSDP, 56, 57, Pt. 1: Washington (U.S. Govt. Printing Office), 521-568.

Aubouin, J., von Huene, R., and Shipboard Scientists, 1982. Leg 84 of the Deep Sea Drilling Project-subduction without accretion: Middle America Trench off Guatemala. Nature, 297:458-460.

Berger, W. H., Adelseck, C. G., Jr., and Mayer, L. A., 1976. Dissolution of carbonate in surface sediments of the Pacific Ocean. $J$. Geophys. Res., 81:2617-2627.

Bray, C., and Karig, D., 1985. Porosity of sediments in accretionary prisms, and some implications for dewatering processes. J. Geophys. Res., 90:768-778.

Coulbourn, W. T., 1981. Tectonics of the Nazca Plate and the continental margin of western South America, $18^{\circ} \mathrm{S}$ to $23^{\circ} \mathrm{S}$. In Kulm, L. D., Dymond, J., Dasch, E. J., and Hussong, D. M. (Eds.), Nazca Plate, Crustal Formation and Andean Convergence: Ann Arbor (Geol. Soc. Am. Mem.), 154:587-618.

Coulbourn, W. T., Hesse, R., Azéma, J., and Shiki, T., 1982. A summary of sedimentology of Deep Sea Drilling Project Leg 67 sites: the Middle America Trench and slope off Guatemala-an active margin transect. In Aubouin, J., von Huene, R., et al., Init. Repts. DSDP, 67: Washington (U.S. Govt. Printing Office), 759-774.

Creager, J. S., Scholl, D. W., and Shipboard Scientific Party, 1973. Site 186 and Site 187. In Creager, J. S., Scholl, D. W., et al., Init. Repts. DSDP, 19: Washington (U.S. Govt. Printing Office), 217-277 and $279-290$

Den, N., and Yoshii, T., 1970. Crustal structure of the Tosa Deep-sea Terrace and Nankai Trough. Pt. 2. Interpretations. In Hosino, M., and Aoki, H. (Eds.), Island Arc and Ocean: Tokyo (Tokai University Press), pp. 95-100. (In Japanese with English abstract)
Fitch, T. J., and Scholz, C. H., 1971. Mechanism of underthrusting in southwest Japan: a model of convergent plate interactions. J. Geophys. Res., 76:7260-7292.

Helwig, J., and Hall, G. A., 1974. Steady-state trenches. Geology, 2: 309-316.

Hilde, T. W. C., Wageman, J. M., and Hammond, W. T., 1968. The structure of Tosa Terrace and Nankai Trough off southeastern Japan. Deep-Sea Res., 16:67-75.

Hussong, D., and Shipboard Scientific Party, 1978. Leg 60 ends in Guam. Geotimes, 23(10):19-22.

Hussong, D. M., Uyeda, S., et al., 1982. Init. Repts. DSDP, 60: Washington (U.S. Govt. Printing Office).

Ingle, J. C., Jr., Karig, D. E., and Shipboard Scientific Party, 1975. Site 298. In Karig, D. E., Ingle, J. C., Jr., et al., Init. Repts. DSDP, 31: Washington (U.S. Govt. Printing Office), 317-350.

Kanamori, H., and Tsumura, K., 1971. Spatial distribution of earthquakes in the Kii Peninsula, Japan, south of the Median Tectonic Line. Tectonophysics, 12:327-342.

Karig, D. E., Ingle, J. C., Jr., et al., 1975. Init. Repts. DSDP, 31: Washington (U.S. Govt. Printing Office).

Karig, D. E., Kagami, H., and DSDP Leg 86 Scientific Party, 1983. Varied responses to subduction in Nankai Trough and Japan Trench forearcs. Nature, 304:148-151.

Karig, D. E., and Sharman, G. F., 1975. Subduction and accretion in trenches. Geol. Soc. Am. Bull., 86:377-389.

Kulm, L. D., von Huene, R., and Shipboard Scientific Party, 1973. Site 175, Site 181, and Site 182. In Kulm, L. D., von Huene, R., et al., Init. Repts. DSDP, 18: Washington (U.S. Govt. Printing Office), $169-212,449-500$, and 501-513.

Langseth, M., and Shipboard Scientific Party, 1978. Transects begun. Geotimes, 23(3):22-26.

Larson, R. L., et al., 1984. The Bedrock Geology of the World: Salt Lake City (W. H. Freeman and Co.).

Ludwig, W. J., Den, N., and Murauchi, S., 1973. Seismic reflection measurements of southwest Japan margin. J. Geophys. Res., 78: 2508-2516.

Mogi, A., 1979. An Atlas of the Sea Floor around Japan: Tokyo (University of Tokyo Press).

Moore, J. C., and Biju-Duval, B., 1984. Tectonic synthesis, Deep Sea Drilling Project Leg 78A: structural evolution of offscraped and underthrust sediment, northern Barbados Ridge complex. In BijuDuval, B., Moore, J. C., et al., Init. Repts. DSDP, 78A: Washington (U.S. Govt. Printing Office), 601-621.

Moore, J. C., Biju-Duval, B., and Shipboard Scientists, 1982. Offscraping and underthrusting of sediment at the deformation front of the Barbados Ridge. Geol. Soc. Am. Bull., 93:1065-1077.

Moore, J. C., Biju-Duval, B., and Shipboard Scientific Party, 1984. Site 541 and Site 542. In Moore, J. C., Biju-Duval, B., et al., Init. Repts. DSDP, 78A: Washington (U.S. Govt. Printing Office), 107186 and $187-225$.

Moore, J. C., and Shipboard Scientific Party, 1979. Middle America Trench drilled. Geotimes, 24(10):20-22.

Nasu et al., 1979. Multi-channel Seismic Reflection Data across the Japan Trench, Tokyo (Ocean Research Institute, University of Tokyo), IPOD-Japan Basin Data Series, No. 3.

Nasu et al., 1982. Multi-channel Seismic Reflection Data across Nankai Trough. Tokyo (Ocean Research Institute, University of Tokyo), IPOD-Japan Basic Data Series, No. 4.

Ryan, W. B. F., Hsü, K. J., and Shipboard Scientific Party, 1973. Hellenic Trench-Sites 127 and 128. In Ryan, W. B. F., Hsü, K. J., et al., Init. Repts. DSDP, 13, Pt. 1: Washington (U.S. Govt. Printing Office), 243-322.

Scholl, D. W., and Marlow, M. S., 1974. Global tectonics and sediments of modern and ancient trenches: some different interpretations. In Kahle, C. F. (Ed.), Plate Tectonics Assessments and Reassessments: Tulsa (Am. Assoc. Pet. Geol. Mem.), 23:255-272.

Seely, D. R., Vail, P. R., and Walton, G. G., 1974. Trench-slope model. In Burk, C. A., and Drake, C. L. (Eds.), The Geology of Continental Margins: New York (Springer-Verlag), pp. 249-260.

Seno, T., 1977. The instantaneous rotation vector of the Philippine Sea plate relative to the Eurasian plate. Tectonophysics, 42:209226.

Taira, A., 1981. The Shimanto Belt of southwest Japan and arc-trench sedimentary tectonics. Recent Prog. Nat. Sci. Jpn., 6:147-162. 
Taira, A., Okada, H., Whitaker, J. H. McD., and Smith, A. J., 1982. The Shimanto Belt of Japan: Cretaceous-lower Miocene activemargin sedimentation. In Leggett, J. K. (Ed.), Trench-Forearc Geology: Oxford (Blackwell Sci. Publ., U.K.), pp. 5-26.

von Huene, R., Aubouin, J., and Shipboard Scientists, 1980. Leg 67: the Deep Sea Drilling Project Mid-America Trench transect off Guatemala. Geol. Soc. Am. Bull., 91(1):421-432.

von Huene, R., Langseth, M., Nasu, N., and Okada, H., 1982. A summary of Cenozoic tectonic history along the IPOD Japan Trench transect. Geol. Soc. Am. Bull., 93:829-846. von Huene, R., and Shipboard Scientific Party, 1978. Japan Trench transected. Geotimes, 23(4):16-21.

White, R. S., and Louden, K. E., 1982. The Makran convergent margin: structure of a thickly sedimented convergent plate boundary. In Watkins, J. S., and Drake, C. L. (Eds.), Studies in Continental Margin Geology: Tulsa (Am. Assoc. Pet. Geol. Mem.), 34:499518.

Yoshii, T., Ludwig, W. J., Den, N., Murauchi, S., Ewing, M., Hotta, H., Buhl, P., Asanuma, T., and Sakajiri, 1973. Structure of southwest Japan margin off Shikoku. J. Geophys. Res., 78:2517-2525. 